\title{
Do Constitutions Matter? The Dilemma of a Radical Lawyer
}

\author{
Issa Gulamhussein Shivji*
}

Constitutions don't make revolutions. Revolutions make constitutions. No constitution envisages its own death for that is what a revolution entail. But constitutions matter. Some of the finest constitutions have been erected on ugly socio-economic formations wrought with extreme inequalities and inequities. South Africa and Kenya are examples. But constitutions do matter. Constitutions rarely herald fundamental transformations. They are the product of major transformations to consolidate the new status quo. Yet constitutions do matter. Why do constitutions matter? Why do we need constitutions? Why does every revolution and major change in modern societies birth new constitutions? This is the question I want to reflect on: why do constitutions matter?

A constitution is as much a political as it is a legal document. It is a power map. Deeper structures of a constitution reveal, albeit partially, the constitution of the state is the primary repository of political power. The constitution defines the citizen and expresses the authority of the state over her. It defines and demarcates the rights of the citizen and limits his or her freedom. In turn, the state demands unquestionable loyalty to itself. State authority and citizen loyalty is sanctioned by criminal law which stands for the use of force. Citizen rights and freedoms are sanctioned by civil law which censures individuals and organs, never the state. Citizen's loyalty to the state is taught in our schools as Civics. State authority over the citizen is political, not civic, and politics are embargoed from schools. In the mystified language of politics, the absolute loyalty to the state is called patriotism. It is in the name of patriotism that wars are fought and conflicts between and among ruling classes played out, all at the expense of the lives and freedoms of the people.

I said a constitution is a political document. Now, I extend it - it is also an ideological document. It mystifies citizen loyalty to the state as a civic duty while it

\footnotetext{
* Former Mwalimu Julius Nyerere Chair in Pan-African Studies, University of Dar-es-salaam. Shivji is a 'Tanzanian author and academic, and one of Africa's leading experts on law and development issues. He has taught and worked in universities all over the world'. This is a keynote address delivered to mark the $10^{\text {th }}$ Anniversary of the Constitution of Kenya of 2010.
} 
mesmerises state authority over the citizen as necessary in the interest of society. Rights and freedoms are given by the grace of the state - they are gratuitous. Restrictions and abbreviations of rights and freedoms are a necessity, which, the otherwise benevolent state, has to enforce in the interest of social stability-(read asstate stability). All liberal and liberal-left discourses, whatever their nuances and however anti-establishment they may sound, ultimately reflect and reinforce the ideological apparatus of the state to justify, mystify and mesmerise the state's monopolyof authority and violence to maintain the status quo.

\section{Why then do Constitutions Matter?}

Constitutions are a terrain of struggle, as progressive lawyers like some of you and I would say. It is a cliché but a cliché with some truth and much mystification. Permit me briefly to deconstruct the cliché by asking the following rhetorical questions. Who fights that struggle? At what site? In whose interest? For what purpose? Under what perspective and set of values (which is really a euphemism for ideology!)? Lawyers fight that struggle in courts through litigation in the interest of their clients with a purpose of winning, driven or motivated by a set of liberal values - human rights, accountability, checks and balances, limitation of power etc - values that are anchored in liberal democracy which is the staple on which we have been trained and fed and brought up. What is in it for lawyers? Fees in the pocket, status in society, reputation at the bar, appeasement of the conscience and inflation of the ego. That is a bit harsh. For there are some who do pro bono work probably funded by liberal donor organisations including such dubious funders as George Soros' ‘Open Societies'. (Someof you may know that Soros made his money through speculation on the financial markets or what is better termed as 'casinocapitalism').

But, to be fair, on the margins of such a coterie of elitist lawyers, there exist sincere, well- intentioned and self-sacrificing lawyers who are motivated by their passion for social justice and fight for the rights, dignity and livelihoods of the working people. It is to this group of radical lawyers that I wish to address my following remarks. (And I include myself in this group.)

It is important for us, radical lawyers, to recognise the limits of bourgeois law and constitutions.

Firstly, law, by its very nature, individualises collective demands as individual grievances and disputes. It thus fragments social struggles and undermines solidarity of the working people. 
Secondly, in a litigation it is the lawyer who is the hero while the people are victims or spectators. The hero fights while the spectators cheer. It deprives the people of their self- esteem and militancy. It subverts people's agency.

Thirdly, the struggle moves from the barricades to the barristers thus robbing the people of their schools of struggle which are streets, neighbourhoods and places of production.

Fourthy, while victory goes to legitimise the status quo and the system, defeat results in despondency and hopelessness, and not infrequently, surrender.

Finally, the progressive lawyer is infected even more deeply by the liberal virus, to use Samir Amin's phrase, holding high the placard of change and reform while simultaneously holding down the banner of fundamental transformation.

So, then, the question for the radical lawyer is: Why fight for rights and freedoms and constitutionalism? Why, at all, do constitutions matter? I am sure many a radical lawyer has agonised over this, as I have, over the years in my legal aid and trade union practice. Let me think aloud with you on how a radical lawyer may engage in the rights-struggle while keeping his passion for social justice and transformation alive and undented.

First, a radical lawyer must disinfect herself or himself of the liberal virus. And the most effective vaccine is revolutionary theory and conscientious practice.

Second, a radical lawyer must disabuse herself or himself of the notion that law is neutral and apolitical. It is not. If politics is the concentrated form of economics, as Lenin said, I add, law is the concentrated form of politics. The question is: What kind of politics? Radical politics are not on offer and cannot be picked up from workshops and seminars. Rather they should be learnt from the masses, for real politics are where the masses are.

Third, a radical lawyer must humbly acknowledge that legal struggles are only one front of the social struggles of the working people. Therefore, it cannot be waged in isolation from other fronts of struggles.

Fourth, a radical lawyer should not stop at chanting that a constitution is a terrain of struggle. He or she must go beyond to identify sites of struggle. The sites of struggles which matter to the people are where they live (urban neighbourhoods and village communities) and where they get their livelihoods (land and factories).

Fifth, and finally, a radical lawyer must recognise that the sites of struggle are also sites of organising working people. Unorganised masses are like steam 
that evaporates into air and disappears. But the same steam when captured in an engine pushes the piston and moves the engine.

Stating these guidelines in the abstract rightly sounds esoteric and perhaps unrealistic. It behoves on me to concretise them. I will do so by broadly painting one possible scenario.

Let me use what they call triangulation. My three points will be right to life, freedom of expression and freedom of association. Right to life can be further resolved into right to live with dignity and right to a decent livelihood - in short, right to be human, as Upendra Baxi would have it. It is around these rights that local struggles are strategized and people are mobilised and organised. It is around these rights and freedoms that litigation strategies are worked out. This way of highlighting and focusing on a selected number of strategic rights and freedoms allows one to move away from the fragmented rights-discourse.

This way of crystallising the rights-struggle on the ground also gives radical activists a handle on the demands that should be made of the state at the national level. And here I draw in the concept of commons, both traditional commons - land, water, under-ground and overground natural resources and new commons which are often called public goods. In this I include education, health and sanitation, energy, communications and finance. Here the strategic demand would be to de-commodify and de-privatise the commons. In other words, for the working people to reclaim the commons and liberate them from the clutches of monopoly finance capital assisted by our comprador states. This way of conceptualising, operationalising and strategising on different fronts the rights-struggle and the struggle for the commons would strike an immediate chord in the consciousness of the masses for it is a struggle for their decent livelihoods and human dignity. It is a struggle to facilitate production where energy and finance are important factors. And it is a struggle for education and health of their children. It also becomes a struggle to bring strategic sectors of the economy in the public domain. It is thus a struggle against local compradorial classes and imperialist capital.

Friends and comrades - I have overstepped my boundaries and said more than what you bargained for! Let me end with two remarks. You are commemorating 10 years of your Constitution and launching my friend Willy Mutunga's new edition of the book Constitution-making from the middle. No doubt, in the new Constitution you have a fine product. Many commentators have analysed and will continue to comment on the product. My interest, though, is not so much in the product as the process of making the product, so well captured 
in Willy's book. I had the taste of that process when I was invited to address the National Convention Assembly (NCA), I think, sometime in 2001. I was amazed at the composition of the delegates attending that convention. They were all elected at the grassroots level, mostly working people in their ragtag clothes and women in baibui. The deliberations were in Kiswahili. Willy reminds me that in that meeting I warned walalahoi (working people) not to leave the process in the hands of the walalahai (petty bourgeoisie or the middle class) for they will be betrayed. Apparently, that is what Mutunga documents in his book for the process was driven by the middle class. But - and this is an important 'but' - NCA mothered so many social justice centres which have continued the struggle for social justice in slums and communities. Their demands go beyond constitutional reforms to social reforms. That is the path towards fundamental transformation. Willy tells me that he is planning a sequel which will capture this process in what he wants to call Constitution-(un)making from the bottom. 'Un' is my addition. I say this so that blame is laid at the right quarters. It would be blasphemous to attribute unmaking of the constitution to a former Chief Justice!

With these many words, I thank you for inviting me from across the border to join you in this commemoration. Truly, you are breaking new ground to ground a new African intellectual community; a community of 'Intellectuals without Borders.'

Asanteni sana na kila la beri 
